This item was submitted to Loughborough's Research Repository by the author.

Items in Figshare are protected by copyright, with all rights reserved, unless otherwise indicated.

\title{
The real exchange rate and the output response in four EU accession
} \section{countries}

PLEASE CITE THE PUBLISHED VERSION

PUBLISHER

(c) Loughborough University

LICENCE

CC BY-NC-ND 4.0

\section{REPOSITORY RECORD}

Mills, Terence C., and Eric J. Pentecost. 2019. "The Real Exchange Rate and the Output Response in Four EU Accession Countries”. figshare. https://hdl.handle.net/2134/1128. 
This item was submitted to Loughborough's Institutional Repository by the author and is made available under the following Creative Commons Licence conditions.

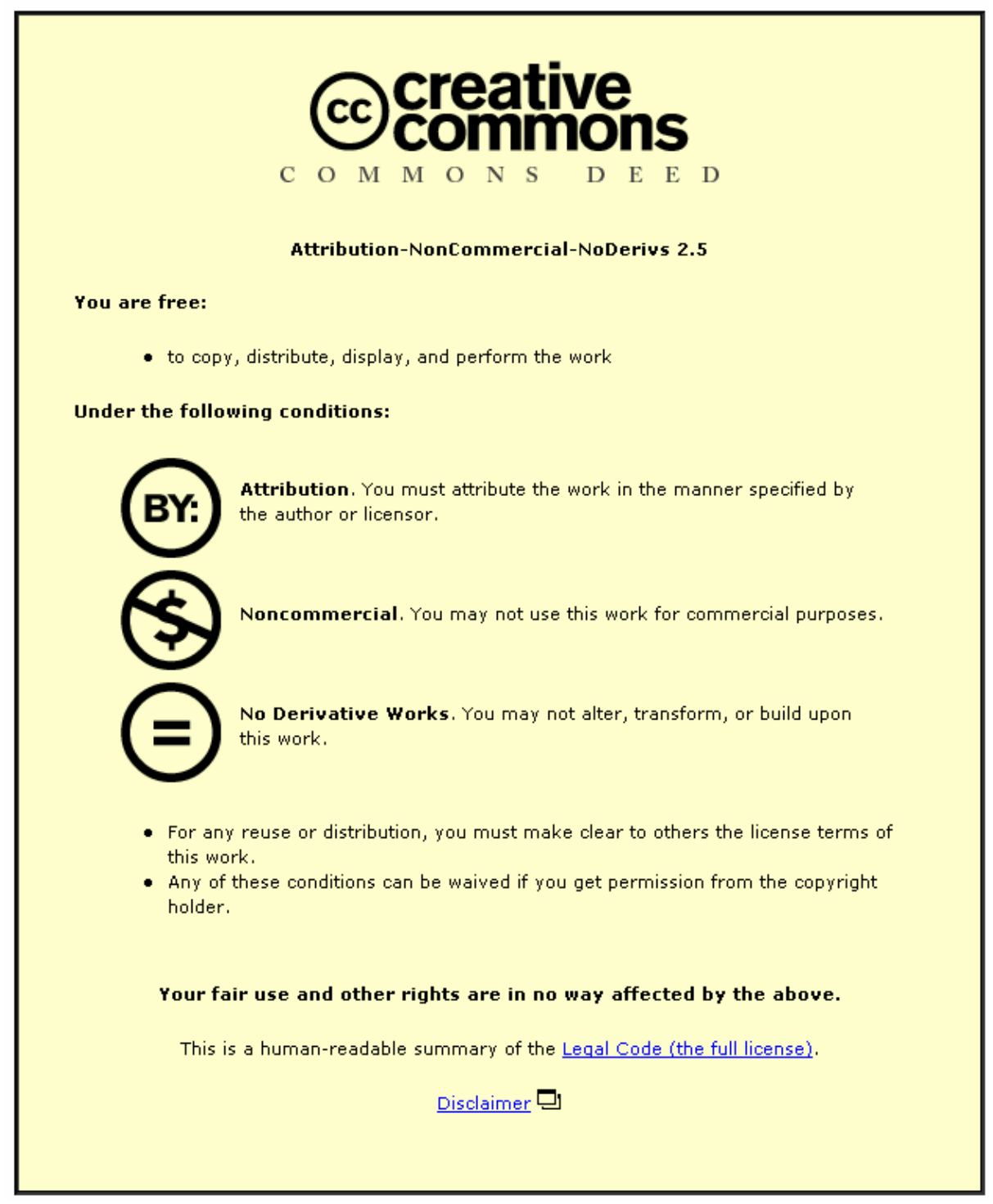

For the full text of this licence, please go to: http://creativecommons.org/licenses/by-nc-nd/2.5/ 


\section{Department of Economics}

Business Cycle Volatility and Economic Growth Research Paper No. 00-4

\section{The Real Exchange Rate and the Output Response in Four EU Accession Countries}

Terence C. Mills and Eric J. Pentecost

August 2000

This paper forms part of the ESRC funded project (Award No. L1382511013)

"Business Cycle Volatility and Economic Growth: A Comparative Time Series Study", which itself is part of the Understanding the Evolving Macroeconomy Research programme. 


\begin{abstract}
This paper estimates the response of output to changes in the real exchange rate in four transitional economies. The theoretical effect is ambiguous since the demandside effect works against the supply-side effect. On the demand-side, a depreciation of the real exchange rate should improve competitiveness and enhance the demand for output, whereas the supply-side effect suggests that output may fall as competitiveness improves since this makes imported inputs more expensive, thereby raising the cost of production. The econometric results show that, inter alia, the real exchange rate is not an important determinant of the long-run level of GDP in the Czech Republic or Hungary, but that a real appreciation leads to a persistent fall in output in Poland and a sustained rise in output in Slovakia. A short run real appreciation leads to a temporary decline in output growth in both the Czech Republic and Slovakia.
\end{abstract}




\section{Introduction}

The relationship between the real exchange rate and the level of output is an important and controversial issue for transitional economies. There are two principal issues: firstly, the level and determinants of the real exchange rate; and secondly, the effects of changes in the real exchange rate on the level of output of the economy. The first issue has been considered for transition economies by Halpern and Wyplosz (1997). They found that, following liberalisation, the real exchange rate usually first depreciates sharply and then appreciates, with the most important determinant of real exchange rate appreciation being increases in labour productivity. The second issue concerning the output effect of real exchange rate movements has yet to be addressed in the context of transition economies, and is the purpose of this paper. ${ }^{1}$

The traditional literature suggests that a real exchange rate depreciation will lead to a rise in the demand for domestic output as the gain in competitiveness improves the trade balance, assuming that the sum of the import and export elasticities of demand exceed unity. ${ }^{2}$ On the other hand, there are several theoretical reasons why, contrary to the traditional view, devaluation can be contractionary and generate a decline in economic activity. First, a nominal devaluation can result in some contractionary pressures on aggregate demand, which could more than offset the traditional expenditure-switching effect. For example, a devaluation will raise the price level, generating a negative real balance effect (Alexander, 1952), which will, in turn, lower aggregate demand and output. Another channel through which devaluation can lower aggregate demand relates to its effect on income distribution. A devaluation can redistribute income from groups with a low marginal propensity to save to groups with a high marginal propensity to save, resulting in a decline in demand and output (see Krugman and Taylor, 1978). Second, in addition to these demand-side effects there are a number of supply-side channels through which devaluation can be contractionary. For example, a devaluation may reduce aggregate supply because the increased costs of imported inputs reduces the demand for them and hence of domestic production (Hanson, 1983). Argy and Salop (1983) and Lizondo and Montiel (1989) also suggest that reduced profits in the non-traded sector, caused by the higher real costs of imported inputs, especially oil, lead to a contraction in output after a devaluation.

\footnotetext{
${ }^{1}$ There is a literature on the empirical effects of real exchange rate changes on output in developing economies: see for example, Branson (1986) or Edwards (1986). These papers suggest an initial contraction in output following a devaluation, but then a subsequent rise in output which more than offsets the initial decline.

${ }^{2}$ The Marshall-Lerner condition is only a necessary, and not sufficient, condition. If the devaluation is successful then incomes will rise, which will in turn lead to a higher level of imports. Therefore, for the trade balance to unambiguously improve, the sum of the demand elasticities must exceed unity (see, for example, Pentecost, 1993).
} 
In this paper a reduced-form equation for output is derived from a set of structural equations depicting goods and money market equilibrium and a cost-plus pricing model of the supply-side. The supply-side is chosen as a half-way house between a fully administered price system, characteristic of centrally planned economies, and a fully flexible price system, which is more characteristic of the advanced industrial economies. This structure implies that the reduced form for output depends upon both demand and supply factors, such as the level of the real money stock, the level of real wages and the level of the real exchange rate. This reduced form relation for output is estimated for four transitional economies, the Czech Republic, Hungary, Poland and Slovakia over the period 1992 to 1998, using recently developed econometric techniques that allow a high degree of robustness to the problems inherent in analysing short data sets. The empirical model therefore enables us to distinguish between short-run and long-run effects of a change in the real exchange rate on the level of output.

The structure of the paper is as follows. Section 2 sets out a simple structural macroeconomic model, including the supply-side response to changes in the real exchange rate, based on an extended IS-LM framework and derives the reduced form to be estimated. Section 3 briefly considers the data set. Section 4 explains the econometric methodology used and Section 5 discusses the results that are obtained from the estimation of the model. Section 6 summarises the main findings, discusses the limitations of the analysis and offers some suggestions for future work.

\section{The Model}

To investigate the output response to changes in the real exchange rate a simple macroeconomic model is postulated whereby prices are cost determined and the level of output is determined by aggregate demand. Not withstanding the analysis in the introduction, the demand-side effects of devaluation are assumed to have expansionary effects on output. The potential contractionary effects of devaluation are assumed to operate through the supply-side effects of devaluation on import prices and the costs of production. The result will be that the response of output to changes in the real exchange rate will depend upon whether the supply-side or demand-side effects of changes in the real exchange rate prevail.

The domestic money market equilibrium condition is given as:

$$
h-p_{c}=\alpha y-\beta i
$$


where $h$ is the logarithm of the high powered (base) money supply, $p_{c}$ is the logarithm of the consumer price level, $y$ is the logarithm of output and $i$ is the nominal rate of interest. In an open economy the logarithm of the consumer price level is a linear combination of the logarithms of domestic output prices, $p$, and world import prices in terms of domestic currency units, $e+p^{*}$, where $e$ is defined as the log of the domestic price of foreign currency:

$$
p_{c}=(1-\eta) p+\eta\left(e+p^{*}\right)=p+\eta\left(e+p^{*}-p\right)=p+\eta q
$$

where $\eta$ denotes the share of imports in domestic GDP and $q$ is the defined as the real exchange rate, such that a rise in $q$ denotes a real depreciation of the home currency.

The domestic price level is based on a mark-up, $\mu$, on average costs, which consist of money wages relative to productivity, i.e., unit labour costs, $W / A$, and the domestic currency price of imports, $P_{m}$. Thus the domestic price level is written as:

$$
P=(1+\mu)\left\lfloor(W / A)^{\theta} P_{m}^{1-\theta}\right\rfloor
$$

Expressing the domestic price of imports as the product of the foreign price level and the exchange rate and assuming for simplicity that the mark up is zero, taking logs gives

$$
p=\theta \bar{\Phi}+(1-\theta)\left(e+p^{*}\right)
$$

where $\varpi$ is the log of unit labour costs. Substituting (4) and (2) into (1) gives the money market equilibrium as:

$$
m=\theta(1-\eta) w+(\eta \theta+(1-\theta)) q+\alpha y-\beta i
$$

where $m=h-p$ is the logarithm of the real money supply and $w=\Phi-p$ is the logarithm of real unit costs.

Goods market equilibrium is written as:

$$
y=-\gamma(i-\pi)+\tau q
$$

Equation (6) says that the demand for domestic output depends inversely on the real rate of interest, where $\pi$ is the expected rate of inflation, and directly on the logarithm of the real exchange rate, $q$. 
To close the model an expression is needed to endogenise the expected rate of inflation. We postulate a simple regressive expectations model, such that:

$$
\pi=\phi(\bar{p}-p)=\phi\left(\theta(\Phi-p)+(1-\theta)\left(e+p^{*}-p\right)=\phi(\theta w+(1-\theta) q)\right.
$$

This says that inflation is expected to rise if the equilibrium price level, $\bar{p}$, is above the actual price level. The equilibrium price level is in turn equal to the price level from equation (3). Thus expected inflation rises if costs of production rise faster than domestic output prices.

Combining equations (5), (6) and (7) gives the final reduced from for output:

$$
y=a_{0}+a_{1} m+a_{2} q+a_{3} w
$$

where

$$
\begin{aligned}
& a_{1}=(\beta+\alpha \gamma)^{-1} \gamma>0 \\
& a_{2}=(\beta+\alpha \gamma)^{-1}\{\beta[\delta+\gamma \lambda(1-\theta)]-\gamma[1-\theta(1+\eta)]\}<>0 \\
& a_{3}=(\beta+\alpha \gamma)^{-1}\{\gamma \theta[\beta \lambda-(1-\eta)]\}<>0
\end{aligned}
$$

This reduced form indicates that the evolution of output depends positively on the real money supply, but is ambiguously related to both the real exchange rate and the real wage rate. The ambiguity with respect to the real exchange rate emerges because of the positive demand side effect through the Marshall-Lerner condition, $\delta$, and the negative supply-side effect through import prices. A rise in the real wage may lead to a rise in output if the expected rate of inflation rises in response to a rise in wages, since this reduces the real rate of interest and stimulates output demand. On the other hand, a rise in the real wage rate will reduce the demand for output, by leading to higher prices and a higher nominal interest rate. Which channel dominates is an empirical issue, and may well differ between countries in the sample. The greater the impact of wages on inflation, the greater the chance of output rising in response to a rise in real wages. On the other hand, the greater the effect on the price level, the more likely is output to fall. 


\section{The Data Set}

The data set has been primarily collected from International Financial Statistics (IFS) for the Czech Republic, Hungary, Poland and Slovakia, which are the principal accession economies to the EU. The data is quarterly from either 1992:Q1 or 1993Q1 and for most variables ends in 1998:Q2, giving 28 observations on each country. ${ }^{3}$

The theoretical model has been constructed with minimal data requirements in mind. Thus the need is for data on real output, money wage rates, the money supply and the real exchange rate. There does not seem to be much quarterly GDP data available and so we use the industrial production series from IFS (line 66). Data on money wage rates is also taken from IFS (line 65). The money supply data seems to be consistent across the countries, being from lines 34 or 35 of IFS ${ }^{4}$. Given that there is little interest rate data that is comparable across these countries, it seems preferable to assume that the interest rates are endogenously determined and the money supply exogenously controlled by the central banks. Since the countries' concerned each have some exchange rate flexibility this is perhaps not a serious assumption. Consumer price data is consistent across the countries (line 64 in IFS). The nominal exchange rate is measured as the average market exchange rate. The bilateral real exchange rates employed for each country are defined as the domestic currency price of one German Mark.

\section{The Statistical Model}

The modelling framework that we employ is that of Pesaran, Shin and Smith (2000), henceforth referred to as PSS, which we refer to for technical details. Thus we consider the following conditional error correction model (ECM)

$$
\Delta y_{t}=c_{0}+c_{1} t+\pi y_{t-1}+\vartheta \mathbf{x}_{t-1}+\sum_{i=1}^{p} \varphi_{i} \Delta \mathbf{z}_{t-1}+\omega \Delta \mathbf{x}_{t}+u_{t}
$$

Here $y_{t}$ is the logarithm of industrial production, $\mathbf{x}_{t}$ is a $k$-vector of explanatory variables, $\mathbf{z}_{t}=\left(y_{t}, \mathbf{x}_{t}^{\prime}\right)$ and $u_{t} \sim I N\left(0, \sigma^{2}\right)$. PSS show that (9) can be obtained from a $\operatorname{VAR}(p+1)$ in $\mathbf{z}_{t}$ under the assumptions that (i) the elements of $\mathbf{z}_{t}$ are either purely

\footnotetext{
${ }^{3}$ There is, however, no quarterly data for the Czech Republic prior to 1993. For 1992 the relevant series were constructed on the basis of allocating two-thirds of the series to the Czech Republic and one third to Slovakia.

${ }^{4}$ Jacob Zoltan from the Central Bank of Hungary kindly provided us with quarterly data for Hungarian money supply and money wages.
} 
$I(1)$, purely $I(0)$ or cointegrated, (ii) that $\left\{\mathbf{x}_{t}\right\}_{t=1}^{\infty}$ is long-run forcing for $\left\{y_{t}\right\}_{t=1}^{\infty}$. The first assumption excludes the possibility of seasonal unit roots and explosive roots. The second assumption precludes feedback from the level of $y_{t}$ to $\mathbf{x}_{t}$ (but not necessarily from $\Delta y_{t}$ ) and restricts consideration to cases in which there exists at most one conditional level relationship between $y_{t}$ and $\mathbf{x}_{t}$, irrespective of the level of integration of the process $\left\{\mathbf{x}_{t}\right\}_{t=1}^{\infty}$.

A third assumption, that $\left\{\mathbf{x}_{t}\right\}_{t=1}^{\infty}$ is mutually cointegrated of order $r, 0 \leq r \leq k$, along with further assumptions concerning the rank of the long-run multiplier matrix of the VAR, are used to demonstrate that, if $\pi \neq 0$, then there is a conditional level relationship between $y_{t}$ and $\mathbf{x}_{t}$ defined by

$$
y_{t}=\theta_{0}+\theta_{1} t+\Theta \mathbf{x}_{t}+v_{t}, \quad t=1,2, \ldots
$$

where $\theta_{i}=c_{i} / \pi, i=0,1$, and $\Theta=\vartheta / \pi$. If $\pi \neq 0$ and $\vartheta=0$, then clearly from (9) $y_{t}$ is $I(0)$ whatever the value of $r$ and that $\Delta y_{t}$ depends only on its own lagged level $y_{t-1}$ in the conditional ECM (9) and not on the lagged levels $\mathbf{x}_{t-1}$ of the forcing variables. If, on the other hand, $\pi=0$ and $\vartheta \neq 0$, then $\Delta y_{t}$ depends only on the lagged level $\mathbf{x}_{t-1}$, so that $y_{t} \sim I(1)$ whatever the value of $r$. If both $\pi=0$ and $\vartheta=0$ then there are no level effects in (9), no possibility of any level relationship between $y_{t}$ and $\mathbf{x}_{t}$, and again $y_{t} \sim I(1)$ whatever the value of $r$.

The absence of any level effects in the conditional ECM (9) is therefore a test of the joint hypothesis $\pi=0$ and $\vartheta=0$. PSS show that the usual Wald and $F$ statistics can be used, but that their asymptotic distributions depend on the dimension and cointegrating rank, $k$ and $r$, of the forcing variables $\mathbf{x}_{t}$, as well as on whether restrictions are placed upon how the intercept and trend in (9) are modelled. In particular, they show that the critical values take on lower and upper bounds when $r=k$ and $r=0$ respectively. These two sets of critical values thus provide critical value bounds covering all possible classifications of $\mathbf{x}_{t}$ into $I(0), I(1)$ and mutually cointegrated processes, and PSS suggest the following bounds procedure to test the null $\pi=\vartheta=0$ : If the computed statistics fall outside the critical value bounds, a conclusive decision can be made without needing to know the cointegration rank $r$ of the $\mathbf{x}_{t}$ process. If, however, the statistics fall within these bounds, inference is inconclusive and explicit knowledge of the cointegration rank $r$ of the forcing variables is needed to proceed further.

PSS also consider the $t$-test of $\pi=0$, which was originally proposed by Banerjee, Dolado and Mestre (1998). This statistic can also be used with a bounds procedure similar to the joint test above. PSS show that both procedures are consistent. 


\section{Empirical Modelling}

The vector $\mathbf{x}_{t}$ typically contains the logarithms of the real money supply, $m_{t}$, real wages, $w_{t}$, and the real exchange rate, $q_{t}$. The unavoidably short samples have several implications for empirical modelling. The lag length $p$ must be kept short, and fortunately it was found that setting $p=1$ was appropriate, on the basis of residual diagnostic checks, for each country. Nevertheless, this leaves only $T=26$ observations available for estimation ( $T=22$ for Hungary and Slovakia). The critical values provided by PSS, which are computed using $T=1,000$, must therefore be questionable. Since they also depend on the dimension of $\mathbf{x}_{t}$, the Monte Carlo simulations were therefore repeated so that they were tailored to the particular settings of $T$ and $k$ existing for each country. These critical value bounds are reported in Table 1 and, not surprisingly, are considerably larger than the 'asymptotic' critical values. To improve the power of the tests, the statistics were calculated after all insignificant $\Delta \mathbf{z}_{t}$ and $\Delta \mathbf{z}_{t-1}$ have been excluded: these statistics are reported in Table 2. While this could introduce pre-testing problems, it was felt that with these small samples such problems were of a secondary nature. For Poland, a 'one-off' dummy variable was included to deal with an outlier in 1993:Q3. Such a dummy, denoted $D U M_{t}$ below, does not affect the critical values of the tests.

Since $c_{1}$ is significant for the Czech Republic, Hungary and Poland, attention is focused on $F_{I V}, F_{V}$ and $t_{V}$, the tests corresponding to the presence of a non-zero trend in (9). For the Czech Republic and Poland, all tests are significant at less than the 0.01 level, providing conclusive evidence of a long-run levels relationship.

The evidence is not as strong for Hungary, but $F_{V}$ falls within the 0.05 bounds and $F_{I V}$ falls within the 0.10 bounds. Given this, we still proceed on the basis that a long-run relationship nevertheless exists for Hungary. For Slovakia, the trend is insignificant, and so attention focuses on $F_{I I I}$ and $t_{I I I}$, both of which are significant at less than the 0.01 level, again providing conclusive evidence of a long-run levels relationship.

Given this compelling evidence of a long-run levels relationship in each country, irrespective of the integration properties of the regressors, parsimonious versions of the ECM (9) were then constructed, which are reported below. Noting that from (9) and (10) we have

$$
\Delta y_{t}=c_{0}+c_{1} t+\pi v_{t-1}+\sum_{i=1}^{p} \varphi_{i} \Delta \mathbf{z}_{t-1}+\omega \Delta \mathbf{x}_{t}+u_{t}
$$

where

$$
v_{t-1}=y_{t-1}-\Theta \mathbf{x}_{t-1}
$$


Table 1

(a) Czech Republic and Poland

Critical Value Bounds of the $\boldsymbol{F}$-Statistic

\begin{tabular}{|l|l|l|l|l|l|l|l|l|}
\hline$T=26$ & \multicolumn{2}{|c|}{0.100} & \multicolumn{2}{c|}{0.050} & \multicolumn{2}{c|}{0.025} & \multicolumn{2}{c|}{0.010} \\
\hline \multicolumn{1}{|c|}{$K=3$} & $I(0)$ & $I(1)$ & $I(0)$ & $I(1)$ & $I(0)$ & $I(1)$ & $I(0)$ & $I(1)$ \\
\hline I & 2.37 & 3.60 & 2.99 & 4.42 & 3.66 & 5.27 & 4.54 & 6.44 \\
\hline II & 2.88 & 3.90 & 3.51 & 4.72 & 4.20 & 5.54 & 5.14 & 6.74 \\
\hline III & 3.23 & 4.50 & 4.00 & 5.45 & 4.76 & 6.49 & 5.84 & 7.84 \\
\hline IV & 3.66 & 4.69 & 4.45 & 5.65 & 5.24 & 6.61 & 6.39 & 7.89 \\
\hline V & 4.20 & 5.44 & 5.12 & 6.58 & 6.07 & 7.72 & 7.49 & 9.30 \\
\hline
\end{tabular}

Critical Value Bounds of the $t$-Statistic

\begin{tabular}{|l|l|l|l|l|l|l|l|l|}
\hline$T=26$ & \multicolumn{2}{|c|}{0.100} & \multicolumn{2}{c|}{0.050} & \multicolumn{2}{c|}{0.025} & \multicolumn{2}{c|}{0.010} \\
\hline \multicolumn{1}{|c|}{$K=3$} & $I(0)$ & $I(1)$ & $I(0)$ & $I(1)$ & $I(0)$ & $I(1)$ & $I(0)$ & $I(1)$ \\
\hline I & -1.80 & -3.06 & -2.16 & -3.50 & -2.50 & -3.87 & -2.91 & -4.37 \\
\hline III & -2.65 & -3.57 & -3.03 & -4.01 & -3.36 & -4.41 & -3.78 & -4.93 \\
\hline V & -3.25 & -4.02 & -3.64 & -4.50 & -4.01 & -4.92 & -4.48 & -5.43 \\
\hline
\end{tabular}

(b) Hungary and Slovakia

Critical Value Bounds of the $\boldsymbol{F}$-Statistic

\begin{tabular}{|l|l|l|l|l|l|l|l|l|}
\hline$T=22$ & \multicolumn{2}{|c|}{0.100} & \multicolumn{2}{c|}{0.050} & \multicolumn{2}{c|}{0.025} & \multicolumn{2}{c|}{0.010} \\
\hline \multicolumn{1}{|c|}{$K=3$} & $I(0)$ & $I(1)$ & $I(0)$ & $I(1)$ & $I(0)$ & $I(1)$ & $I(0)$ & $I(1)$ \\
\hline I & 2.49 & 3.73 & 3.19 & 4.65 & 3.92 & 5.60 & 4.90 & 7.03 \\
\hline II & 3.07 & 4.09 & 3.80 & 4.98 & 4.56 & 5.96 & 5.74 & 7.40 \\
\hline III & 3.42 & 4.68 & 4.28 & 5.76 & 5.17 & 6.93 & 6.59 & 8.58 \\
\hline IV & 3.89 & 4.94 & 4.79 & 6.07 & 5.79 & 7.24 & 7.14 & 8.98 \\
\hline V & 4.44 & 5.71 & 5.48 & 7.03 & 6.62 & 8.44 & 8.28 & 10.41 \\
\hline
\end{tabular}

Critical Value Bounds of the $t$-Statistic

\begin{tabular}{|l|l|l|l|l|l|l|l|l|}
\hline$T=26$ & \multicolumn{2}{|c|}{0.100} & \multicolumn{2}{c|}{0.050} & \multicolumn{2}{c|}{0.025} & \multicolumn{2}{c|}{0.010} \\
\hline \multicolumn{1}{|c|}{$K=3$} & $I(0)$ & $I(1)$ & $I(0)$ & $I(1)$ & $I(0)$ & $I(1)$ & $I(0)$ & $I(1)$ \\
\hline I & -1.81 & -3.08 & -2.17 & -3.52 & -2.52 & -3.95 & -2.94 & -4.44 \\
\hline III & -2.69 & -3.60 & -3.10 & -4.08 & -3.47 & -4.53 & -3.93 & -5.09 \\
\hline V & -3.29 & -4.06 & -3.71 & -4.57 & -4.14 & -5.06 & -4.63 & -5.69 \\
\hline
\end{tabular}

Notes: Case I: no intercept and no trend, $c_{0}=c_{1}=0$.

Case II: restricted intercept and no trend, $c_{1}=0, c_{0}=-\pi \mu_{y}-\vartheta \mu_{x}$, so that (9) is

$$
\Delta y_{t}=\pi\left(y_{t-1}-\mu_{y}\right)+\vartheta\left(\mathbf{x}_{t-1}-\mu_{x}\right)+\sum_{i=1}^{p} \varphi_{i} \Delta \mathbf{z}_{t-1}+\omega \Delta \mathbf{x}_{t}+u_{t}
$$

Case III: unrestricted intercept, no trend, $c_{0} \neq 0, c_{1}=0$. 
Case $I V$ : unrestricted intercept, restricted trend, $c_{0} \neq 0, c_{1}=-\pi \gamma_{y}-\vartheta \gamma_{x}$, so that (9) is

$$
\Delta y_{t}=c_{0}+\pi\left(y_{t-1}-\gamma_{y} t\right)+\vartheta\left(\mathbf{x}_{t-1}-\lambda_{x} t\right)+\sum_{i=1}^{p} \varphi_{i} \Delta \mathbf{z}_{t-1}+\omega \Delta \mathbf{x}_{t}+u_{t}
$$

Case $V$ : unrestricted intercept, unrestricted trend, $c_{0} \neq 0, c_{1} \neq 0$.

The critical values are computed via stochastic simulations using 40,000 replications: see PSS for the DGPs appropriate for each case.

Table 2

\section{$F$ - and $t$-Statistics for Testing the Existence of a Levels Relationship}

\begin{tabular}{ccccccc}
\hline & $F_{I I I}$ & $F_{I V}$ & $F_{V}$ & $t_{I I I}$ & $t_{V}$ & $t_{t}$ \\
\hline Czech Republic & - & $11.95^{a}$ & $14.82^{a}$ & - & $-7.36^{a}$ & 5.30 \\
Hungary & - & $4.55^{c}$ & $5.68^{b}$ & - & $-2.94^{d}$ & 2.569 \\
Poland & - & $19.42^{a}$ & $10.73^{a}$ & - & $-2.64^{d}$ & -3.50 \\
Slovakia & $30.05^{a}$ & $22.33^{a}$ & $27.78^{a}$ & $10.59^{a}$ & $-9.96^{a}$ & 0.04 \\
\hline
\end{tabular}

Notes: ${ }^{a}$ indicates that the statistic lies above the 0.01 upper bound;

${ }^{b}$ indicates that the statistic falls within the 0.05 bounds;

${ }^{c}$ indicates that the statistic falls within the 0.10 bounds;

${ }^{d}$ indicates that the statistic falls below the 0.10 bound;

$t_{t}$ is the $t$-statistic for testing $c_{1}=0$.

In these equations, coefficient standard errors are shown in parentheses, probability values are shown in square brackets, $A U T O(k)$ and $A R C H(k)$ are LM tests for $k$ th order residual autocorrelation and $\mathrm{ARCH}$, respectively, and $N O R M$ is a test of normality of the residuals.

\section{Czech Republic}

$$
\Delta y_{t}=\begin{aligned}
& 5.026+0.0123 t+0.110 \Delta^{2} m_{t}-0.443 \Delta w_{t-1}+0.550 \Delta q_{t-1}-1.265 \hat{v}_{t-1} \\
& (0.839)(0.0020)(0.042)
\end{aligned}
$$


$y_{t}=\underset{(0.052)}{0.091 m_{t}}+\underset{(0.155)}{0.626} w_{t}+\hat{v}_{t}$

$R^{2}=0.83 ; \quad \hat{\sigma}=1.59 \%$;

$A U T O(4)=0.46[0.76] ; \quad A R C H(1)=0.44[0.51] ; \quad N O R M=6.50[0.04]$

\section{Hungary}

$$
\begin{aligned}
& \Delta y_{t}=-0.590+0.0101 t+0.155 \Delta w_{t}-0.103 \Delta w_{t-1}-0.832 \hat{v}_{t-1} \\
& \begin{array}{llll}
(0.522) & (0.0025) & (0.049) & (0.057)
\end{array} \\
& y_{t}=0.507 w_{t}+\hat{v}_{t} \\
& (0.143) \\
& R^{2}=0.59 ; \quad \hat{\sigma}=1.57 \% \\
& A U T O(4)=0.44[0.78] ; \quad A R C H(1)=0.04[0.84] ; \quad N O R M=0.97[0.61]
\end{aligned}
$$

\section{Poland}

$$
\begin{aligned}
& \Delta y_{t}=-0.372-0.0083 t+0.245 \Delta m_{t}+0.138 \Delta w_{t-1}-0.297 \hat{v}_{t-1}-0.038 D U M_{t} \\
& \left.\begin{array}{lllll}
(0.065) & (0.0020) & (0.031) & (0.063) & (0.046)
\end{array}\right)^{t-1} \quad(0.008) \\
& y_{t}+w_{t}-q_{t}=0.597\left(m_{t}-w_{t}\right)+\hat{v}_{t} \\
& R^{2}=0.92 ; \quad \hat{\sigma}=0.75 \% ; \\
& \text { AUTO }(4)=3.37[0.04] ; \quad A R C H(1)=0.05[0.82] ; \quad N O R M=2.04[0.36]
\end{aligned}
$$

\section{Slovakia}

$$
\begin{aligned}
\frac{y_{t}+y_{t-1}}{2}= & \begin{array}{l}
3.520+0.162 \Delta m_{t}-0.134 \Delta w_{t-1}+0.641 \Delta q_{t}-0.176 m_{t-1} \\
(0.324)(0.041) \quad(0.031)
\end{array} \\
& +0.488 w_{t-1}-0.400 q_{t-1} \\
& (0.035) \quad(0.101)
\end{aligned}
$$

$R^{2}=0.97 ; \quad \hat{\sigma}=1.15 \% ；$

AUTO $(4)=2.51[0.10] ; \quad A R C H(1)=0.09[0.77] ; \quad N O R M=0.67[0.74]$ 
In these models, there are two marginally significant residual diagnostic tests, the autocorrelation test for Poland and the normality test for the Czech republic. With regards to the former, additional lagged $\Delta y_{t}$ were insignificant, while the nonnormality in the latter is simply the consequence of a single outlying residual only just over two standard errors in size.

Certain data based restrictions have been imposed in the models. $\Delta^{2} m_{t}$ appears as a regressor in the model for the Czech Republic, so that industrial production growth is positively related to the acceleration in real money. The ECM for Poland can be expressed equivalently as $y_{t}=0.6 m_{t}-1.6 w_{t}+q_{t}$, so that the restrictions $\Theta_{1}+\Theta_{2}=-1$ and $\Theta_{3}=1$ have been imposed (and found to be acceptable). Perhaps the most interesting sets of restrictions are those found in the Slovakian specification. Since the restriction $\pi=-2$ cannot be rejected, this implies that that we can transform the dependent variable to $\Delta y_{t}+2 y_{t-1}=y_{t}+y_{t-1}$, so that it can be interpreted as the two-year average of industrial production. This is sensible because the evolution of both $\Delta y_{t}$ and detrended $y_{t}$ display a saw-tooth pattern of negative first order autocorrelation. Since $\bar{y}_{t}=\left(y_{t}+y_{t-1}\right) / 2$ is stationary, the coefficient on the ECM term is (minus) unity and the model can be written as

$$
\begin{aligned}
& \Delta \bar{y}_{t}=3.520+0.162 \Delta m_{t}-0.134 \Delta w_{t}+0.641 \Delta q_{t}-\hat{v}_{t-1} \\
& \bar{y}_{t}=-0.176 m_{t}+0.488 w_{t}-0.400 q_{t}+\hat{v}_{t}
\end{aligned}
$$

Impulse response functions for the Czech Republic, Hungary and Poland are shown in Figure 1: equilibrium is reached after just one quarter for Slovakia and thus plots of these impulse responses are omitted. The various response functions show that the four EU accession economies are structurally diverse in that they exhibit different output responses to real exchange rate and real wage shocks. Competitiveness is not significant in the long-run for the Czech Republic or Hungary and, although it is statistically significant for both Poland and Slovakia, the output responses are very different.

For Poland, a one percent real devaluation leads, after a delay of one quarter, to a monotonic rise in output of one per cent after approximately two years - an effect very similar to that found by Mitchell and Pentecost (2001). This would suggest a slow but sustained response of output to exchange rate movements. For Slovakia, however, a one per cent real devaluation leads to a fall of 0.4 per cent, which is completed after just one quarter. This can be interpreted as the supply effect of a depreciation through consumer prices dominating the product price effect on the demand side. 
Figure 1: Impulse response functions for output

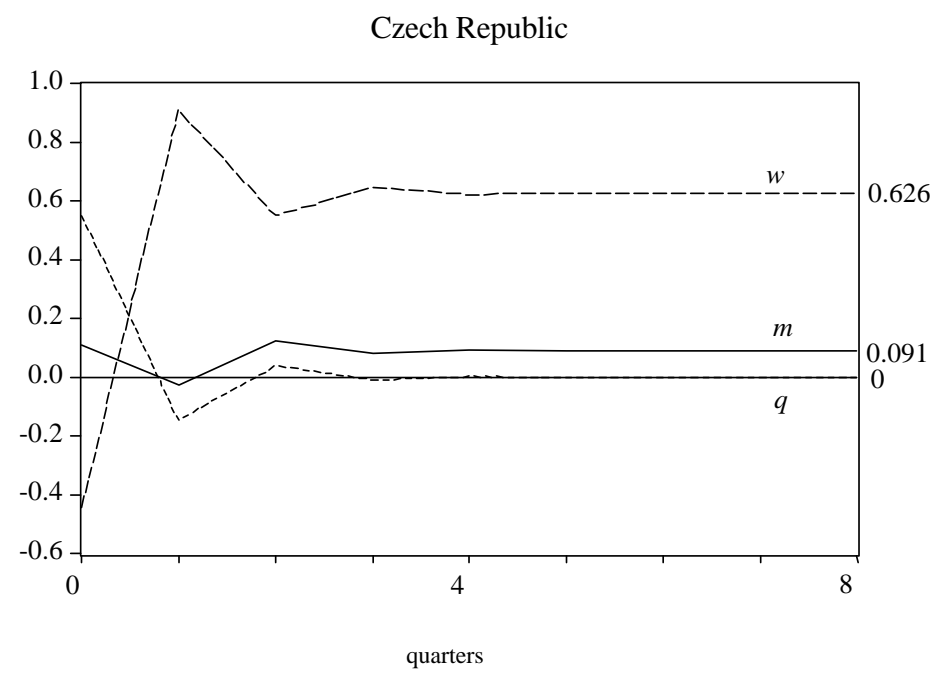

Hungary

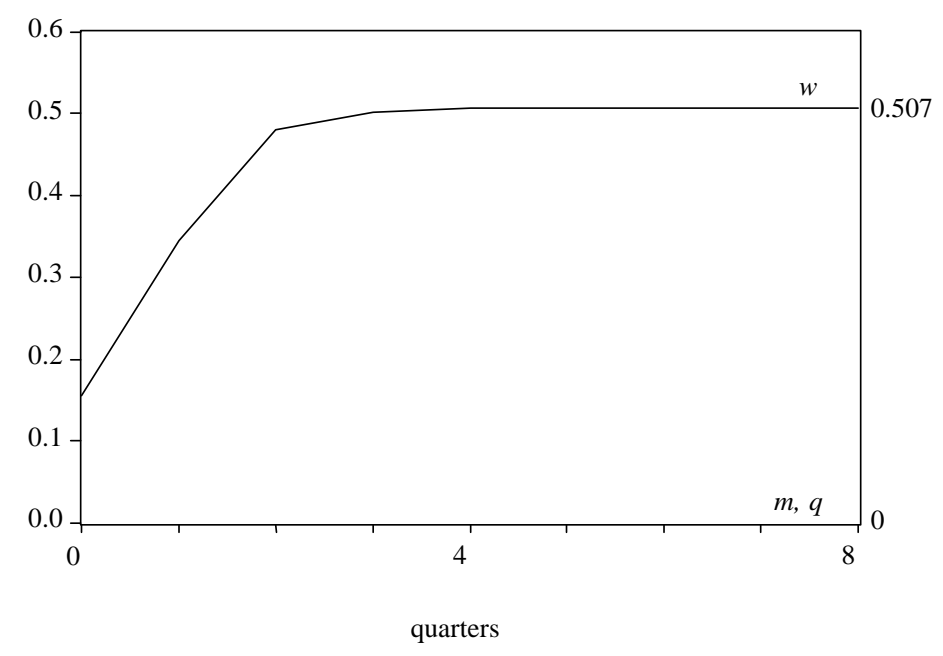

Poland

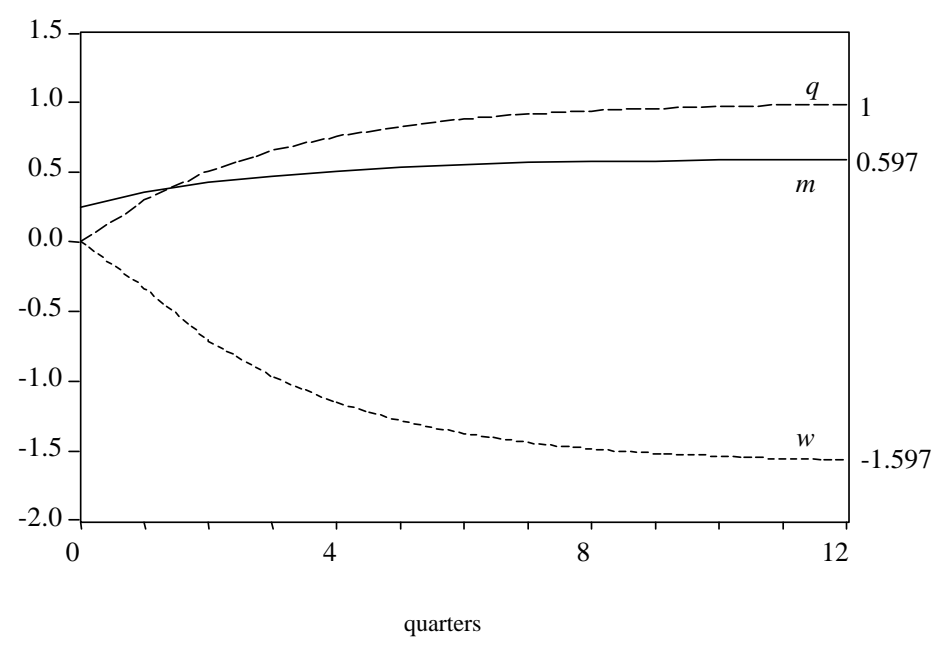


A real exchange rate change has no long-run effect on output in the Czech Republic, although there are short-run effects that last about a year: output initially rises sharply following a one per cent rise in the real exchange rate, only to decline during the first quarter. There is thus some output overshooting in both upward and downward directions, but after a year output is back on its long-run time path. Exchange rate changes thus generate output volatility without affecting its long-run level.

Real wages are positively related to output in the long-run except in Poland. From the point of view of the underlying model, this suggests that real wages rise in response to productivity gains in the Czech Republic, Hungary and Slovakia, but that in Poland the dominant force is that higher real wages raise production costs and reduce output. Long-run output elasticities with respect to the real wage are very similar for the three former countries, $(0.63,0.51$ and 0.49$)$ but, in contrast, Poland's real wage elasticity is much larger at -1.60 , which has the policy implication that real wage rises in Poland are detrimental to output growth.

The short-run responses of output to real wage rises are also very different between the four economies. Output declines monotonically in Poland, but rises monotonically in Hungary, and in both cases adjustment is virtually completed within two years. On the other hand, both the Czech Republic and Slovakia experience immediate output falls which are then more than offset after one quarter. There is thus overshooting, with the initial decline perhaps reflecting that cost effects run ahead of productivity gains, although the latter eventually, and quickly, dominate.

Finally, although perhaps of less interest in this study, in all countries except Hungary (where output and real money are unrelated), output rises in response to an increase in real money. In general, the real money elasticities of output are smaller than the other elasticities, perhaps reflecting the importance of supply side reforms in these economies.

\section{Conclusions}

We have set out a simple macroeconomic model characteristic of a transition economy and derived a reduced form equation for output, in which GDP depends positively on the real money supply and ambiguously on both the real exchange rate and the real wage rate. The econometric estimation shows that the response of GDP in these four economies to a real depreciation is diverse. In particular, the fact that there are sustained output gains for Poland suggests any membership of the EU that may reduce nominal depreciation would be to the detriment of output and employment. On 
the other hand, for the Czech Republic and Hungary - which are more open economies - the consequence of greater exchange rate rigidity would have no longrun implications for output. For Slovakia, a persistent real depreciation serves to reduce domestic output as costs rise relative to demand. The real wage effects on output are similar for the Czech Republic, Hungary and Slovakia, in that real wage rises enhance the demand for output, but for Poland the long run effect is negative.

These very different output responses to real exchange rate and wage changes suggest that some care will be needed when these countries accession terms to the EU are discussed. This research suggests that it would be a mistake to treat all the economies as identical. They are different, not only in size and openness, but also in the speed and direction with which liberalisation has proceeded. This is reflected in our different output responses to real exchange rate changes.

\section{References}

Alexander, S.S. (1952), 'Effects of a devaluation on a trade balance,' IMF Staff Papers 3, 263-278.

Argy, V. and Salop, J. (1983), 'Prices and output effects of monetary and fiscal expansion in a two-country world under flexible exchange rates,' Oxford Economic Papers 35, 228-246.

Banerjee, A., Dolado, J. and Mestre, R. (1998), "Error-Correction Mechanism Tests for Cointegration in Single-Equation framework", Journal of Time Series Analysis, 19, 267-283.

Branson, W.H. (1986), 'Stabilisation, stagflation and investment incentives: The case of Kenya 1975-80,' in Edwards, S. and Ahamed, L. (eds), Economic Adjustment and Exchange Rates in Developing Countries, Chicago: University of Chicago Press.

Edwards, S. (1986), 'Are devaluations contractionary?' Review of Economics and Statistics, August, 501-508.

Halpern, L. and Wyplosz, C. (1997), 'Equilibrium exchange rates in transition economies,' IMF Staff Papers 44, December, 430-461.

Hanson, J. (1983), 'Contractionary devaluation, substitution in production and consumption and the role of the labour market,' Journal of International Economics, 14, 179-189.

Krugman, P. and Taylor, L. (1978), 'The contractionary effects of devaluation,' Journal of International Economics, 8, 445-456. 
Lizondo, J.S. and Montiel, P. (1989), 'Contractionary devaluation in developing countries: an analytical overview,' IMF Staff Papers, 36, March, 182-227.

Mitchell, A.J. and Pentecost, E.J. (2001), 'The Supply-Side Response to Exchange Rate Changes in Four Transition Economies: A Panel Data Study,' in C. Papazoglou and E.J. Pentecost (editors), Exchange Rate Polices and the Supply-Side Response in Transition Economies. Basingstoke: Macmillan.

Pentecost, E.J. (1993), Exchange Rate Dynamics, Aldershot: Edward Elgar.

Pesaran, M.H., Shin, Y. and Smith, R.J. (2000), "Bounds Testing Approaches to the Analysis of Level Relationships", University of Cambridge, DAE Working Paper No. 9907, Revised February 2000. 